\section{Polychondritis Associated with Chronic Hepatitis C Virus Infection}

\section{To the Editor:}

Chronic hepatitis $\mathrm{C}$ virus infection (HCV) is often associated with extrahepatic manifestations; the majority are immunologically mediated. It has been hypothesized that $\mathrm{HCV}$, which is both a hepato- and a lymphotropic virus, might exert a chronic stimulating effect on the immune system, resulting in B-lymphocyte proliferation ${ }^{1,2}$. The well established immunologic complications of HCV infection are mixed cryoglobulinemia, membranoproliferative glomerulonephritis, leukocytoclastic vasculitis, porphyria cutanea tarda, sialadenitis, and autoantibody production such as rheumatoid factor (RF). Other possible associations have been reported, like B-cell non-Hodgkin's lymphomas, polyarteritis nodosa, autoimmune cytopenia, and autoimmune thyroiditis ${ }^{3}$. We describe a patient with chronic HCV infection who developed acute auricular chondritis (Figure 1A) with scleritis (Figure 1B).

A 56-year-old African American man presented with a 2-week history of increasing pain and swelling of both ears. He also had bilateral pain and redness of eyes associated with photophobia. He denied any sick contacts, trauma, fever, chills, weight changes, difficulty breathing, hoarseness, oral or genital ulcers, joint pain, genital discharge, or rash. He was afebrile with diffuse swelling and erythema of both ears extending into the ear canal but sparing the noncartilagenous part of the ear. Eye examination revealed scleritis with normal visual acuity. C-reactive protein was $3.2 \mathrm{mg} / \mathrm{dl}$ and erythrocyte sedimentation rate was $88 \mathrm{~mm} / \mathrm{h}$. RF was positive at 23.5 $\mathrm{IU} / \mathrm{ml}$; serum protein electrophoresis revealed polyclonal gammopathy

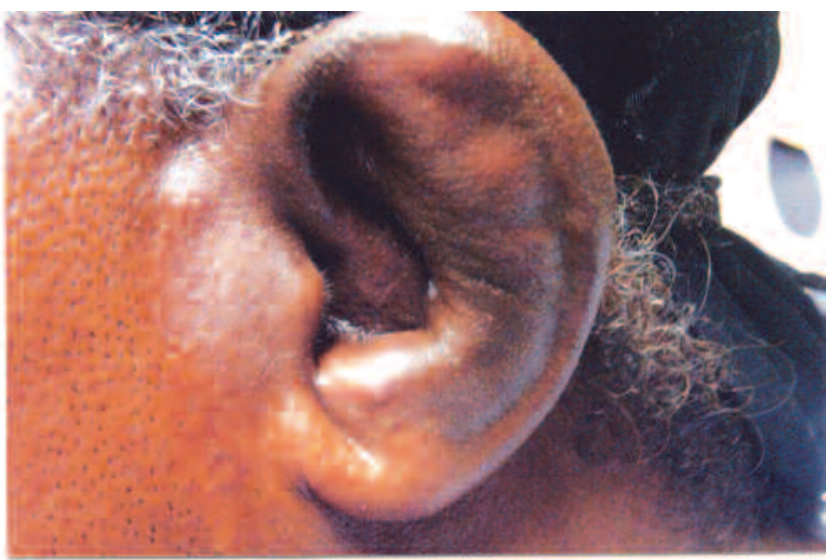

A

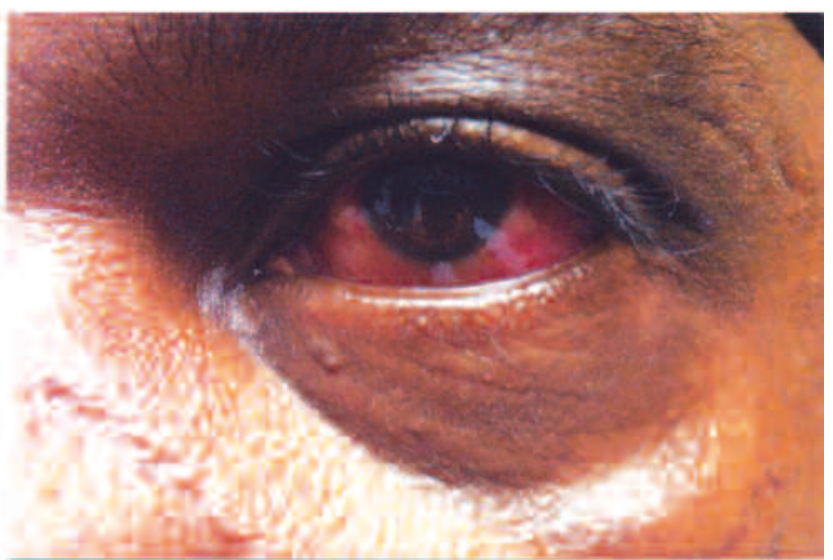

B

Figure 1. Our patient with chronic HCV infection developed acute auricular chondritis (A) with scleritis (B). with decreased albumin, and IgG3 was elevated at $167 \mathrm{mg} / \mathrm{dl}$. Antibodies to $\mathrm{HCV}$ antigen were positive with a viral load of $1,340,000 \mathrm{IU} / \mathrm{ml}$. Antineutrophil cytoplasmic antibody (ANCA) testing was positive by indirect immunofluorescence with a cytoplasmic (C) staining pattern. Testing by enzyme immunoassay demonstrated no antibodies for proteinase 3 . The HIV test was negative; anti-collagen type 2 antibodies and cryoglobulins were not detected. Complements were normal. He was felt to have auricular chondritis (Figure 1) and scleritis (Figure 2), presumed to be associated with HCV infection. Treatment was initiated with prednisone $60 \mathrm{mg} /$ day, with good response. Prednisone dose was gradually reduced over several months. He was then referred to the liver clinic for treatment of HCV infection, but declined treatment with pegylated alpha-interferon and ribavirin. He had a recurrence of his symptoms when he discontinued prednisone and has needed moderate doses of prednisone to control the symptoms.

Relapsing polychondritis is a rare disease of unknown etiology and pathogenesis ${ }^{4}$. The pathogenesis is considered to be autoimmune, based on increased frequency of human leukocyte antigen (HLA)-DR4 in these patients, and detection of antibodies to type II collagen. Histopathology of the involved cartilage reveals inflammation of perichondrium with neutrophils, eosinophils, lymphocytes, and plasma cells. Immunofluorescence studies may show presence of immunoglobulin and C3 complement deposits along the chondrofibrous junction.

We have no direct evidence that the patient's HCV infection and polychondritis are related, but we postulate that HCV infection may be triggering the polychondritis. Some chronically HCV-infected patients have extrahepatic manifestations including cryoglobulinemia and autoantibody production, such as rheumatoid factors, anti-thyroid antibodies, and other non-organ-specific antibodies. The mechanism leading to the production of these antibodies, although not fully understood, appears to be nonspecific activation of the immune system triggered by the viral infection ${ }^{5}$. One such mechanism is molecular mimicry between $\mathrm{HCV}$ polyprotein and self-antigens, which in turn primes the immune system, leading in time to everexpanding self-reactivity ${ }^{6}$.

Chronic HCV infection results in sustained B-cell stimulation. Various mechanisms have been postulated for chronic stimulation of B-cells by HCV. Elevated serum B-lymphocyte activating factor (BAFF) has been found in chronic $\mathrm{HCV}$-infected subjects compared to healthy controls ${ }^{7}$. HCV-infected subjects with clinical and laboratory features of autoimmunity were found to have the highest levels of $\mathrm{BAFF}^{8}$. It has been postulated that $\mathrm{HCV}$ may stimulate B-cells through 3 different pathways: the B-cell receptor recognizing the viral antigens, the $\mathrm{CD} 81$ molecule on the surface of B-cells binding to the HCV envelope 2 protein and CD19-CD21 complex engaging the $\mathrm{C} 3 \mathrm{~d}$ opsonized viral particles, all of them acting in concert to lower the B-cell activation threshold ${ }^{9}$. The B-lymphocyte stimulator (BlyS) belongs to the human tumor necrosis factor superfamily of cytokines, induces upregulation of CD21 on B-cells, and selectively expands the population of terminally differentiated plasma cells, leading to increased immunoglobulin production. $\mathrm{HCV}$ is also implicated in upregulation of Blys $\mathrm{S}^{10,11}$.

That our patient has positive assay for RF and hypergammaglobulinemia with elevated IgG3 suggests that immune activation could have been triggered by $\mathrm{HCV}$, leading in turn to inflammation in the cartilage. The exact pathogenetic mechanism causing polychondritis remains to be determined. We describe an association and cannot prove causality. There is a report describing this association in a patient with mixed cryoglobulinemia ${ }^{12}$.

SAUD ALVI, MD; MARINA N. MAGREY, MD, Assistant Professor of Medicine, Department of Medicine, Division of Rheumatology, Case Western Reserve University, MetroHealth Campus, 2500 Metro Health Drive, Cleveland, Ohio 44109, USA. Address correspondence to Dr. Magrey; E-mail: mmagrey@metrohealth.org

\section{REFERENCES}

1. Ferri C, Monti M, La Civita L, Longombardo G, Greco F, Pasero $\mathrm{G}$, et al. Infection of peripheral blood mononuclear cells by 
hepatitis $\mathrm{C}$ virus in mixed cryoglobulinemia. Blood 1993;82:3701-4.

2. Perl A, Gorevic PD, Ryan DH, Condemi JJ, Ruszkowski RJ, Abraham GN. Clonal B cell expansion in patients with essential mixed cryoglobulinemia. Clin Exp Immunol 1989;76:54-60.

3. Saadoun D, Landau DA, Calabrese LH, Cacoub PP. Hepatitis C-associated mixed cryoglobulinaemia: a crossroad between autoimmunity and lymphoproliferation. Rheumatology 2007;46:1234-42.

4. Kent PD, Michet CJ Jr, Luthra HS. Relapsing polychondritis. Curr Opin Rheumatol 2004;16:56-61.

5. Ferri S, Muratori L, Lenzi M, Granito A, Bianchi FB, Vergani D. HCV and autoimmunity. Curr Pharm Des 2008;14:1678-85.

6. Bogdanos DP, Choudhuri K, Vergani D. Molecular mimcry and autoimmune liver disease: vitrous intentions, malign consequences. Liver 2001;21:225-32.

7. Migita K, Abiru S, Maeda Y, Komori A, Ito M, Fujiwara S, et al. Elevated serum BAFF levels in patients with autoimmune hepatitis. Hum Immunol 2007;68:586-91.
8. Toubi E, Gordon S, Kessel A, Rosner I, Rozenbaum M, Shoenfeld $\mathrm{Y}$, et al. Elevated serum B-lymphocyte activating factor (BAFF) in chronic hepatitis $\mathrm{C}$ virus infection: association with autoimmunity. J Autoimmun 2006;27:134-9.

9. Pileri P, Uematsu Y, Campagnoli S, Galli G, Falugi F, Petracca R, et al. Binding of hepatitis C virus to CD81. Science 1998;282:938-41.

10. Fabris M, Quartuccio L, Sacco S, De Marchi G, Ferraccioli G, Migone TS, et al. B-lymphocyte stimulator (BLyS) upregulation in mixed cryoglobulinaemia syndrome and hepatitis $C$ virus infection. Rheumatology 2007;46:37-43.

11. Sène D, Limal N, Ghillani-Dalbini P, Saadoun D, Piette JC, Cacoub P. Hepatitis C virus-associated B-cell proliferation - the role of serum B lymphocyte stimulator (BLyS/BAFF). Rheumatology 2007;46:65-9.

12. Herrera I, Concha R, Molina EG, Schiff ER, Altman RD. Relapsing polychondritis, chronic hepatitis $\mathrm{C}$ virus infection, and mixed cryoglobulemia. Semin Arthritis Rheum 2004;33:388-403.

J Rheumatol 2011;38:10; doi:10.3899/jrheum.101338 